Mid-American Review of Sociology

2. An emphasis on the importance of systematic conceptualization, particularly of concepts that are at the core of Marxist theory. This involves both careful attention to definitions of concepts and to the logical coherence of repertoires of interconnected concepts. My longstanding preoccupation with refining the concept of class structure, particularly the "middle class," would be an example of this.

3. A concern with a relatively fine-grained specification of the steps in the theoretical arguments linking concepts, whether the arguments be about causal processes in the construction of explanatory theories or about logical connections in the construction of normative theories. This commitment to elaborating the details of arguments is reflected in one of the hallmarks of Analytical Marxism: the use of explicit, systematic models of the processes being studied. The nature of these models may vary quite a bit, from formal mathematical models to less formal causal models. But in each case there is a belief that the possibility of theoretical advance is enhanced when we are able to generate systematic explicit models of the processes under study.

4. The importance accorded to the study of microfoundations of macrosocial phenomena, frequently through a focus on the intentional action of individuals.

A commitment to these principles does blur the line between Marxism and nonMarxist traditions. This has lead some critics of Analytical Marxism to argue that analytical Marxism is a vehicle for exiting Marxism, not reconstructing it. What, it might be asked, remains Marxist in analytical Marxism? What makes analytical Marxism Marxist is its preoccupation with an agenda of problems embedded in the Marxist tradition, in particular problems that cluster around class analysis, scientific socialism and class emancipation. The questions Analytical Marxists ask are thus anchored in these defining themes of Marxism. The answers they come up with, however, may or may not be characteristically "Marxist" ${ }^{m}$. In the end, the choice of staying Marxist presents itself again and again. Analytical Marxism may generate a sufficient metamorphosis in the nature of the Marxist edifice, that in spite of my decision not to move, I will end up living in a different house.

\section{A PARENT'S VIEW OF A KID GROWING UP IN LAWRENCE}

\author{
Beatrice A. Wright \\ University of Kansas
}

Mid-American Review of Sociology, 1991, Vol. XV, No. 2:15-19

Alan Sica invited me to speak about Erik at this centennial celebration, stating that "your view of how this famous sociologist developed would only augment his own fascinating remarks." Of course I was delighted to do so. I was nonplussed, however, about what to say, and Erik was worried that I would embarrass him. I reassured him by pointing out that, after all, he was a product of the times, the town, his family, including his grandparents who lived in Lawrence at the time, and of course himself; any of his triumphs, therefore, would be triumphs extending to many others as well. In what I have to say, I hope to be able to show that.

To jog my memory of telling events, I proceeded to rummage through files and boxes of treasures and mementoes of the growing-up years of our children. Whenever I came across something noteworthy, I jotted it down. I can assure you that I could talk for hours about what I uncovered. But you need not worry about that, for what follows is but a sample of a variety of things that went into the emergence of Erik as Erik.

One of the main reasons we decided to join the University was because we felt that Lawrence would be a good place to rear children. From the start Erik found himself in a world of wonderful happenings. He attended the KU nursery school, so full of things to build and do with other children. I remember how pleased parents were to have him in their carpool because the children, instead of poking at each other, would be held in rapt attention by his fanciful stories. He still is a great story teller, and I believe that the delight of the preschoolers then is part of his own delight to this very day when making up silly and adventuresome stories to a group of children who clamor for more.

I recall that when Erik was in the first grade, he recounted that his teacher had said there were three glasses in a quart and he said, no, there were four. He was troubled about the disagreement. We reassured him that there were four glasses in a quart. When he returned from school the next day, he had a tale to tell. He told us that when he again said that there were four glasses in a quart, his teacher poured three glasses into a quart container, and showed him that there was no more room for a fourth. Perplexed he was. We then explained the notion of standard-sized glasses, which he promptly passed on to his teacher, who replied that she used tumblers and let the issue go at that. I mention this incident to show that the teacher did not squelch him, but rather allowed his own searching for answers. I believe that this was true for most of his school experiences.

The local newspaper, the Lawrence Journal World, did much to let the children know that they were important. Here are two news photos, one showing Erik with other children listening to a fairy tale at the city library's 
regular Saturday morning "Children's Story Hour." The other shows Erik as a seven-year-old with a group of boys being instructed by their coach as members of the Jayhawk Baseball League which was sponsored by the Recreation Commission's summer program. Can't you imagine how good the children felt seeing their pictures in the paper?

Erik always liked to draw, especially imaginary figures speaking imaginary languages and doing imaginary things, mostly funny. He had the opportunity to enter an art contest for physician's children when he was ten. I would have forgotten about this were it not for the retrieved local newspaper account which reported that Erik's drawing received honorable mention and would be displayed at the AMA convention in New York City. As it turned out, his sister, Colleen, is now the acknowledged artist in the family.

Then there was a great music program for all children that started in the fourth grade. The children could try out an instrument for a while, after which they selected the one they wanted to concentrate on. Erik first chose the trumpet and then switched to the violin. The following summer, the children played a concert in South Park, the main park in town, which was attended by appreciative families and friends. There was a news photo of Erik with other players on that occasion, and a later one showing Erik as a sixth grader with his violin together with other instrumentalists.

Some of you here knew Karel Blaas, a professor in the fine arts department at KU. Karel became Erik's beloved violin and viola teacher. I am certain that Erik retains a special feeling of indebtedness to Karel for that musical experience. Karel was also a violin maker, and made an instrument especially for Erik. And as a thirteen-year-old, Erik went to Music and Art Camp, held at the University each summer, and joined the orchestra. Now you know how it came to pass that he was able to fiddle barn dances for social fun and relaxation a few years ago, following the sociology meeting ["Bringing Class Back In"] at which you invited him to speak.

Music recalls the "Snow Goose," a wonderful story by Paul Gallico to which Erik wrote a musical score when he was. 16. The music. was prepared for six instruments played by his friends: flute (Nancy Hitt), harmonica (Woody, Erik's brother), clarinet (David Leonard), trumpet (Tim Gilles), French horn (Chris Saricks), and viola (Erik). Now you can see why there was such a curious assortment of instruments. I mentioned the names of the instrumentalists because some of you here know them and their families. These young people belonged to the youth group of the Unitarian Fellowship. Erik arranged to perform the concert at that Fellowship, and later at the high school. It needs to be recognized that it was the community that provided both space and audience for the encouragement and pleasure of the youthful musicians. The music was recorded, and when I listen to it, I still find it perfectly beautiful, and I think you would too.

Another local news photo reminded me of the play, "The Long Shadow," in which Erik, age 12, had a role. It was directed by Allen Crafton, the talented drama professor at KU after whom the University's Crafton Theater is now named. The play involves tough times that befall a convict upon his return to society after ten years in prison. Who is to say but that this play, so personally experienced, entered The Politics of Punishment, the book Erik wrote some twelve years later?

Those of you who know Erik could predict that he would have joined the high school debate team, and so he did. He was a very good debater, but I must confess that there were times when I regretted that he ever joined the team. On more than one occasion I remember lamenting the fact that in ordinary discussions he adopted the debating style he had learned, namely to demolish the opponent. It took him a while to appreciate that when discussing with others, it was far more important to listen, learn from each other, and garner new ideas than to score points. It could also be predicted that Erik would have been a delegate to "Boys State" where high school juniors assumed duties for one week comparable to local and state elective office. Once again, reports and pictures of both events--the debate team and Boys State--were featured in the local newspaper.

I would not have remembered the following incident were it not for an account of it in the paper. The senior English teacher assigned an article by Arthur M. Schlesinger for the students to read, after which they would write an essay on what Schlesinger thought of writers who condemned social welfare. Erik and a friend decided to contact Schlesinger about his views. They managed this by looking him up in "Who's Who," and discovered that he was an Emeritus Professor living in Cambridge, whereupon they phoned him. The reporter asked them where the idea came from to do this. The friend, pointing to Erik, replied, "His weird brain." When the teacher read Erik's essay which began with, "In a personal telephone interview with Dr. Schlesinger," the teacher thought that Erik was pulling his leg, but was pleased with the end result, and joined in the fun of it with the classmates who knew about the plan all along. I am sharing this incident to show, once again, that Erik's ingenuity was generally appreciated by the school and community.

I've thought about the schools in Lawrence, the fact that the academic program was really not very demanding for someone like Erik. Yet, I believe that it served him well, for it allowed him a lot of free time to become involved with all sorts of self-initiated projects. Erik was always into elaborate projects. I believe that it was the freedom of time and permission to do his thing, that nourished whatever talent and innovativeness he shows today.

Many of you, I'm sure, participated in science fairs, and so did Erik. As a Junior, he submitted a project in biology. He became interested in an idea that stemmed from the fact that the newborn rat is impervious to sound whereas the older rat responds to sound with frantic activity. He wanted to observe what happened during the transition between these two stages. For this he needed activity measurement devices. His consultant became the ever so helpful Bill Balfour, then Professor in the Department of Physiology. He discovered that at first, the young rat responds to sound by freezing and only as it matures does it react with activity. He interpreted the findings in terms of survival, freezing being more likely to ensure safety when the rat is unable to take off with alacrity. This project, "Reaction to Auditory Stimulus in the 
Developing Rat," sent him to the National Science Fair and was published in the Joumal of the Kansas Academy of Science.

For the next science fair, Erik became intrigued with the properties of the Moebius band. A Moebius band is a band joined at the ends that can have any number of twists in it. Curious phenomena result when one cuts the band lengthwise. Depending on the number of twists in the band and number of cuts one makes, the fallout varies in number of interlocking and separate bands that result, as well as in the number of twists they have. Erik set himself the task of developing a formula that would predict the outcome. It took him many months to do so. I recall how he bounded down the stairs one morning full of excitement over an idea that came to him during the night. He got out of bed to jot it down lest he forgot it. This project, "Analysis of the Total Number of Twists Resulting from Cutting any Order of Moebius Band with any Number of Cuts," was also published by the Joumal of the Kansas Academy of Science. I believe that the fact that it won first place in mathematics at the National Science Fair, caused Harvard to shift his name from the waiting list to admission status. Parenthetically, I would like to add that we informed our children that we would be happy if they attended $\mathrm{KU}$, for we knew they could get a fine education here.

By now you may be wondering whether there were any inklings of Erik's interest in social science during these years. He had so many interests, that of course there were inklings. Here are a few examples. When he was 13 , he polled 30 children about their preferences for books and movies. He was interested in gender differences, and of course found them. Four years later he did a much larger survey, this time on the "The image of the presidency." To score the more than 1000 questionnaires, he pulled a Tom Sawyer deal by inviting friends to the house to help him, after which they had a party. One interesting analysis concerned differences between the image of the office of the presidency and the image of actual presidents. The experience that perhaps clinched his destiny is seen in a letter he wrote to his sister who was away at college at the time. One of three courses he took at the University while a senior in high school was a course in political science. About that course he wrote, "The course in political science has grabbed me into its clutches. Dean [Francis] Heller, [Associate] Dean of the College, is the teacher and leads the class in such animated discussion that $I$ really find it hard to contain myself." This last example is also testimony to the important role played by the University during his formative years.

Thus far I have talked about Erik growing up in a town with its settings, with teachers and friends. But what about the influence of his parents? If I were to single out anything, I would single out two qualities of our relationship that may have had a special influence. One is that both of us, his father and I, welcomed with genuine pleasure, even delight, the unfolding curiosity and creativity of the children, and this was equally true of the grandparents. The other is that we shared a concern about basic humanitarian values. That these views coincide with Erik's reflections is seen in a personal note he inscribed to us in his book, The Politics of Punishment. He wrote: "Two things which you gave me as I grew up are deeply embodied in this book: one is enthusiasm--for ideas, for writing, for creating; the other is humanism--a concern for life and a commitment to work to improve it. To say 'thank you' is to barely touch my feelings, but know that I am deeply grateful in ways which grow stronger as a I grow older."

Even as an adolescent, his interest in values and ethics is apparent. $\mathrm{He}$ barely turned 16 when he wrote Act VI as an epilogue to "The Tragedy of Macbeth." Macbeth is now dead, but neither the witches nor those Macbeth killed would get him off the hook. Among the many recriminations and sage counsel intoned in the epilogue, appears this couplet:

"For evil makes not of good, evil

But fills the void where goodness should have been."

You may be interested to learn that in my own book I felt a need to make explicit twenty "value-laden beliefs" that have guided my work.

I would like to conclude by quoting from "The Thoughts of Erik Olin Wright in the Spring of 1967 at Twenty Years of Age" which he wrote while on a research assignment in Paris. His thoughts are divided into six chapters: I. Life and Death, II. God and Morality, III. Politics, Social Change, and the Economic System, IV. My Personality, V. Love, VI. Miscellaneous Thoughts on Social Science and Related Subjects. He gave this volume to his parents for safekeeping, for he planned to write afresh on these topics twenty years later without having reviewed the first edition, a plan which had to be deferred because of the time devoted to family and profession. In the prologue he wrote:

For a very long time I have wanted to sit down and write a treatise on The Thoughts of Erik Olin Wright. But there never was time. And since my life as a student is so filled with study and concentration, whenever I did have spare moments, I generally devoted them to diversion rather than more concentration. But now I am twenty years old, and if I wait too much longer to begin this task, I will no longer be a youth and no longer have the mind and thoughts of me, the youth. I need to record my thoughts and feelings now while they are still naive. I need to do this so that later, when I am wise and learned, I will be able to put myself in perspective, and temper my later wisdom with my present youth.

It is the last sentence that captivates me, and I too wish that whatever wisdom he has, continues to be tempered by the wonderments of his earlier years. 